\title{
Effects of Selenium on Growth and Physiological Characteristics of Tomato Seedlings
}

\author{
Jichao Liao ${ }^{1, a}$, Guochao Sun ${ }^{2, b}$ and Yi Tang ${ }^{2, c *}$ \\ ${ }^{1}$ College of Horticulture, Sichuan Agricultural University, Chengdu, Sichuan, China \\ ${ }^{2}$ Institute of Pomology and Olericulture, Sichuan Agricultural University, Chengdu, Sichuan, China \\ a1498818502@qq.com, b6183090@qq.com, '95459425@qq.com
}

${ }^{*}$ Corresponding author. Jichao Liao and Guochao Sun contributed equally to this work.

\begin{abstract}
Keywords: Selenium; Tomato seedlings; Antioxidant enzyme activity; Physiological property
Abstract: A pot experiment was conducted to study the effects of different concentrations of selenium (Se) on the growth and physiological characteristics of tomato seedlings. The results showed that the biomass, SOD activity, POD activity, CAT activity, soluble protein and soluble sugar content of tomato seedlings increased firstly and then decreased with the increase of Se concentration in soil at $0,5,10,25 \mathrm{mg} / \mathrm{kg}$, and reached the maximum value when Se concentration was $5 \mathrm{mg} / \mathrm{kg}$, which was $3.63 \%, 53.99 \%, 30.54 \%, 40.79 \%, 14.20 \%$ higher than the control, respectively. MDA decreased with the increase of soil Se concentration. Pro showed an increasing trend, and the difference was significant, when Se concentration was $5 \mathrm{mg} / \mathrm{kg}$, it was $68.37 \%$ higher than the control. Therefore, Se can improve the physiological characteristics of tomato seedlings, promote its growth, increase biomass and enhance resistance. And the concentration of 5 $\mathrm{mg} / \mathrm{kg}$ Se was the best.
\end{abstract}

\section{Introduction}

Tomato originated in South America, rich in nutrients, deeply loved by people, now widely cultivated in the world. In 1957, Schwarz and Foltzs first demonstrated that selenium (Se) is an essential nutrient for animals [1]. If the daily Se intake is insufficient, it will lead to the occurrence of large bone disease, Keshan disease, cardiovascular and cerebrovascular diseases and other diseases [2]. Se has anti - cancer, anti - aging, anti-tumor and enhances human immunity and other effects [3]. However, the content of Se in soil is relatively low, in China, $72 \%$ of the regions have different degrees of Se deficiency [4]. Studies have proved that the biological activity of natural organic Se is higher than inorganic Se, and toxicity is less than inorganic Se [5]. Now, with the gradual improvement of living standards, people pay more and more attention to their own health, and the human body Se supplement also began to gradually get attention. It is the safest and most effective way for human body to supplement Se by eating foods with high Se content. However, if fish and meat with high Se content are used for a long time, it will cause excessive Se supplement or even Se poisoning [6, 7]. However, vegetables with good quality and low price can be converted into organic Se needed by human body by absorbing inorganic Se in soil [8]. Some studies have shown that the content of MDA, the production rate of oxygen free radicals and the production of other free radicals decreased with the increase of se concentration, indicating that appropriate se plays an important role in scavenging excessive free radicals and preventing peroxidation in plants [9]. In order to improve the physiological characteristics and enhance the resistance of tomato seedlings, the effects of Se on the growth and physiological characteristics of tomato seedlings were studied by adding different concentrations of Se to soil.

\section{Materials and Methods}

Materials. The experiments were conducted at Sichuan Agricultural University $\left(30^{\circ} 42^{\prime} \mathrm{N}, 103^{\circ} 51^{\prime}\right.$ E), Wenjiang, Chengdu, Sichuan, China. Tomato seeds are provided by the fruit and vegetable research institute of Chengdu campus of Sichuan agricultural university. Se is purchased from 
Chengdu Kelong chemical reagent factory. All chemicals used in experiments were of analytical grade.

Experimental Design. The soil samples were air-dried and passed through a 5-mm mesh in April 2017 , and then $6.0 \mathrm{~kg}$ of soil was weighed into each polyethylene pot $18 \mathrm{~cm} \times 26 \mathrm{~cm}$ (height $\times$ diameter). $\mathrm{Na}_{2} \mathrm{O}_{3} \mathrm{Se} \cdot 5 \mathrm{H}_{2} \mathrm{O}$ solution was added to the soil to divide the Se content into 0 (control), 5 , 10 and $25 \mathrm{mg} / \mathrm{kg}$. The soils were mixed immediately and again after 4 weeks, during this period soil moisture was kept at $80 \%$. Seeds were sterilized in $10 \% \mathrm{Na}_{3} \mathrm{PO}_{4}$ solution for 5 min, rinsed in distilled water five times, and were placed on 9-cm-diameter Petri dishes with three layers of filter paper moistened with distilled water and germinated at $25 \square$ in darkness. Seeds were considered germinated when the seed coat was broken and a radical was visible. After germination, seeds were planted in seedling tray filled with nursery substrate. When the third leaf expanded, uniform seedlings were transplanted into the previously prepared polyethylene pots, one per pot, each treatment repeated three times, randomly placed, and routinely administered.

Statistical Analyses. Statistical analysis was carried out by using SPSS 20.0 statistical software. The data were analyzed by one-way ANOVA, with the least significant difference at the 5\% confidence level.

\section{Results and Discussion}

Biomass of Tomato Seedlings. Table 1 shows that the dry weight of root, stem, leaf and root/shoot ratio of tomato seedlings increased firstly and then decreased with the increase of soil Se concentration, and reached the maximum value when soil Se concentration was $5 \mathrm{mg} / \mathrm{kg}$, which was significantly higher than that of the control $81.49 \%, 79.98 \%, 49.88 \%, 7.35 \%$, respectively. There was no significant difference between the soil Se concentration of $10 \mathrm{mg} / \mathrm{kg}$ and the control. However, when the soil Se concentration was $25 \mathrm{mg} / \mathrm{kg}$, the biomass was significantly lower than that of the control. The results showed that low concentration of Se could promote the accumulation of tomato seedlings biomass, while high concentration of Se could reduce its biomass.

Table 1 Biomass of tomato seedlings

\begin{tabular}{|c|c|c|c|c|}
\hline $\begin{array}{c}\text { Se concentration } \\
(\mathrm{mg} / \mathrm{kg})\end{array}$ & $\begin{array}{c}\text { Root dry weight } \\
\text { (g/plant) }\end{array}$ & $\begin{array}{c}\text { Stem dry weight } \\
\text { (g/plant) }\end{array}$ & $\begin{array}{c}\text { Leaf dry weight } \\
\text { (g/plant })\end{array}$ & $\begin{array}{c}\text { root/shoot } \\
\text { ratio }\end{array}$ \\
\hline 0 & $0.470 \pm 0.036 \mathrm{~b}$ & $2.193 \pm 0.090 \mathrm{~b}$ & $1.263 \pm 0.110 \mathrm{~b}$ & 0.136 \\
\hline 5 & $0.853 \pm 0.074 \mathrm{a}$ & $3.947 \pm 0.117 \mathrm{a}$ & $1.893 \pm 0.091 \mathrm{a}$ & 0.146 \\
\hline 10 & $0.497 \pm 0.031 \mathrm{~b}$ & $2.247 \pm 0.085 \mathrm{~b}$ & $1.263 \pm 0.090 \mathrm{~b}$ & 0.142 \\
\hline 25 & $0.197 \pm 0.015 \mathrm{c}$ & $0.780 \pm 0.075 \mathrm{c}$ & $0.443 \pm 0.032 \mathrm{c}$ & 0.161 \\
\hline
\end{tabular}

Note: there is a significant difference between 0.05 levels of different letters, the same as following tables.

Antioxidant Enzyme Activity of Tomato Seedlings. As shown in table 2, Se treatment had significant effect on SOD, POD and CAT activities of tomato seedlings. Within the range of 0 - 25 $\mathrm{mg} / \mathrm{kg}$, the activities of SOD, POD and CAT increased firstly and then decreased with the increase of soil Se concentration, and reached the peak when soil Se concentration was $5 \mathrm{mg} / \mathrm{kg}$, which increased by $3.63 \%, 53.99 \%$ and $30.54 \%$ respectively compared with the control. When the soil Se concentration was $10 \mathrm{mg} / \mathrm{kg}$, the antioxidant enzyme activity was still higher than the control, but SOD activity and CAT activity were not significant. However, when soil Se concentration was 25 $\mathrm{mg} / \mathrm{kg}$, SOD, POD and CAT activities were lower than the control. The results showed that low concentration Se could increase SOD, POD and CAT activities of tomato seedlings, while high concentration Se could induce stress on tomato seedlings, thus reducing its activity.

Physiological Characteristics of Tomato Seedlings. As shown in table 3, the content of soluble protein and soluble sugar increased firstly and then decreased with the increase of soil Se concentration, and reached the maximum value when soil Se concentration was $5 \mathrm{mg} / \mathrm{kg}$, which was 
significantly higher than that of the control $40.79 \%, 14.20 \%$. There was no significant difference between the control and the control at $25 \mathrm{mg} / \mathrm{kg}$, but it was lower than the control. With the increase of Se concentration in soil, Pro content showed an increasing trend. The treatment of Se concentration was significantly higher than that of the control, $68.37 \%$ higher than that of the control at $5 \mathrm{mg} / \mathrm{kg}$. MDA content decreased with the increase of soil Se concentration. The results showed that low concentration of Se could increase the content of soluble protein, soluble sugar and Pro in plant cells and decrease the content of MDA, thus improving the physiological characteristics of tomato seedlings and enhancing its resistance.

Table 2 Antioxidant enzyme activity of tomato seedlings

\begin{tabular}{|c|c|c|c|}
\hline $\begin{array}{c}\text { Se concentration } \\
(\mathrm{mg} / \mathrm{kg})\end{array}$ & $\begin{array}{c}\text { SOD activity } \\
(\mathrm{U} / \mathrm{g})\end{array}$ & $\begin{array}{c}\text { POD activity } \\
(\mathrm{U} / \mathrm{g})\end{array}$ & $\begin{array}{c}\text { CAT activity } \\
(\mathrm{U} / \mathrm{g})\end{array}$ \\
\hline 0 & $302.40 \pm 7.56 \mathrm{a}$ & $2538.67 \pm 19.96 \mathrm{c}$ & $30.03 \pm 1.30 \mathrm{~b}$ \\
\hline 5 & $313.39 \pm 4.94 \mathrm{a}$ & $3909.33 \pm 25.32 \mathrm{a}$ & $39.20 \pm 2.04 \mathrm{a}$ \\
\hline 10 & $307.17 \pm 8.66 \mathrm{a}$ & $3452.00 \pm 31.16 \mathrm{~b}$ & $30.67 \pm 1.70 \mathrm{~b}$ \\
\hline 25 & $233.12 \pm 5.98 \mathrm{~b}$ & $2420.33 \pm 17.78 \mathrm{~d}$ & $29.60 \pm 0.71 \mathrm{~b}$ \\
\hline
\end{tabular}

Table 3 Physiological characteristics of tomato seedlings

\begin{tabular}{|c|c|c|c|c|}
\hline $\begin{array}{c}\text { Se } \\
\text { concentration } \\
(\mathrm{mg} / \mathrm{kg})\end{array}$ & $\begin{array}{c}\text { Soluble protein } \\
\text { content } \\
(\mathrm{mg} / \mathrm{g})\end{array}$ & $\begin{array}{c}\text { Soluble sugar } \\
\text { content }(\%)\end{array}$ & $\begin{array}{c}\text { Pro content } \\
(\mu \mathrm{g} / \mathrm{g})\end{array}$ & $\begin{array}{c}\text { MDA content } \\
(\mu \mathrm{mol} / \mathrm{L})\end{array}$ \\
\hline 0 & $75.12 \pm 2.25 \mathrm{~b}$ & $1.049 \pm 0.046 \mathrm{bc}$ & $20.11 \pm 1.12 \mathrm{~d}$ & $0.0054 \pm 0.0002 \mathrm{a}$ \\
\hline 5 & $105.76 \pm 5.91 \mathrm{a}$ & $1.198 \pm 0.067 \mathrm{a}$ & $33.86 \pm 1.72 \mathrm{c}$ & $0.0050 \pm 0.0002 \mathrm{a}$ \\
\hline 10 & $79.52 \pm 3.46 \mathrm{~b}$ & $1.097 \pm 0.059 \mathrm{ab}$ & $46.07 \pm 2.47 \mathrm{~b}$ & $0.0045 \pm 0.0002 \mathrm{~b}$ \\
\hline 25 & $69.68 \pm 4.25 \mathrm{~b}$ & $0.956 \pm 0.027 \mathrm{c}$ & $54.45 \pm 2.57 \mathrm{a}$ & $0.0043 \pm 0.0002 \mathrm{~b}$ \\
\hline
\end{tabular}

\section{Conclusions}

Under the condition of Se treatment, with the increase of Se concentration, the biomass of tomato seedlings increased first and then decreased, and the activities of SOD, POD, CAT, soluble protein and soluble sugar of tomato seedlings were consistent with the change trend of biomass. The low concentration of Se promoted the growth and development of tomato seedlings, increased the activity of antioxidant enzymes, and enabled the active oxygen to be removed in time. The physiological characteristics of tomato seedlings were improved with the increase of soluble protein and soluble sugar. Pro content increased with the increase of soil Se concentration, while MDA decreased, thus enhancing the resistance of tomato seedlings. In conclusion, low concentration Se treatment can improve antioxidant enzyme activity, improve its physiological characteristics, promote its growth and development, and enhance resistance. And $5 \mathrm{mg} / \mathrm{kg} \mathrm{Se}$ was the best treatment.

\section{Acknowledgements}

This work was financially supported by the Application Infrastructure Project of Science and Technology Department of Sichuan Province (2016JY0258).

\section{References}

[1] K. Schwarz and C.M. Foltz: Journal of American Chemical Society Vol. 79 (1957), p. 3929. 
[2] G.F. Shi, J. Zhang and H.J. Li: Journal of Trace Elements and Health Research Vol. 18 (2001), p. 51.

[3] C. zhao, J. Ren and C. Xue: Journal of Plant \& Soil Vol. 277 (2005), p. 197.

[4] J.X. Liu, X.H. Lu and Q. Su: Journal of Chinese Agricultural Sciences Vol. 18 (1958), p. 761.

[5] X.B. Zhou, H.Y. Wang and F.D. Xie: Journal of Liaoning Agricultural Sciences Vol. 1 (2002), p. 36 .

[6] G.Q. Yang: Journal of Nutrition Vol. 3 (1992), P. 318.

[7] L.Z. Qu, S.J. Yang and S. Zhuo: Journal of Chinese Agricultural Bulletin Vol. 26 (2010), p. 94.

[8] M.Z. Zhang: Study on physiological and quality effects and molecular regulation of selenium fertilization in tomato, Southwest University (2014).

[9] Z.Q. Zhao, H.L. Zhen and C.G. Zhang: Journal of Ecology Vol. 22 (2003), p. 22. 